\title{
SUSTAINABLE COMPETITIVE ADVANTAGE OF SMES THROUGH RESOURCE AND INSTITUTIONAL-BASED MANAGEMENT: AN EMPIRICAL STUDY OF BATIK SMES IN CENTRAL JAVA, INDONESIA
}

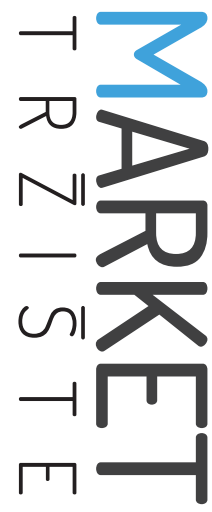

\section{ODRŽIVA KONKURENTSKA PREDNOST MALIH I SREDNJIH PODUZEĆA KROZ RESURSNI I INSTITUCIJSKI MENADŽMENT: EMPIRIJSKO ISTRAŽIVANJE MALIH I SREDNJIH PODUZEĆA, PROIZVOĐAČA BATIKA U SREDIŠNJOJ JAVI, INDONEZIJA}

\author{
Market-Tržište \\ Vol. 31, No. 1, 2019, pp. 61-82 \\ UDK 339.137.2:65.017.2/.3:687(594) \\ DOl http://dx.doi.org/10.22598/mt/2019.31.1.61 \\ Preliminary communication
}

\section{Edy Dwi Kurniatia ${ }^{a}$ Indah Susilowati ${ }^{b}$, Suharnoc}

a Darul Ulum Islamic Centre Sudirman GUPPI University (UNDARIS), Faculty of Economics and Business, Semarang, INDONESIA, e-mail: kurni_edy@yahoo.co.id

${ }^{b}$ Diponegoro University, Faculty of Economics and Business, Semarang, INDONESIA, e-mail: indahsusilowati@undip.ac.id c Universitas Jenderal Soedirman, Faculty of Economics and Business, Purwokerto, INDONESIA, e-mail: suharno@unsoed.ac.id

\begin{abstract}
Purpose - The aim of this study is to find out and to analyze the capacity for developing small and medium-sized enterprises (SMEs) of batik in Central Java, Indonesia. Batik is a traditional hand-crafted dye-resist textile, rich in intangible cultural values that has been passed down for generations. Batik refers to either a technique of wax-resist dyeing applied to whole cloth or cloth made using this technique originating from Indonesia.
\end{abstract}

Design/Methodology/Approach - The primary data was collected by interview method with one hundred

\section{Sažetak}

Svrha - Cilj je ovog istraživanja otkriti i analizirati kapacitete za razvoj malih i srednjih poduzeća za proizvodnju batika u središnjoj Javi u Indoneziji. Batik je tradicionalna ručno izrađena, obojana i otporna tkanina bogata neopipljivim kulturnim vrijednostima koje se prenose $s$ generacije na generaciju. To je tehnika bojanja tkanine uz primjenu voska. Tkanina izrađena korištenjem ove tehnike potječe iz Indonezije.

Metodološki pristup - Primarni podaci prikupljeni su intervjuiranjem stotinu ispitanika, poduzetnika malih 
respondents who are batik entrepreneurs in Central Java, Indonesia. The data collection was carried out using the focus group discussion (FGD) method. Secondary data was used to enrich the analysis. A quantitative model was examined through empirical analysis to fulfill the proposed aim of the research.

Findings and implications - The result of this research shows that business scale, market access capacity, and financial capacity all influence the competitiveness level of batik SMEs. Furthermore, cooperatives can strengthen the influences of market capacity and financial capacity on the competitiveness of SMEs although they are not effective in strengthening the technological and innovative capacities of SMEs. This study shows that SMEs in the form of batik industries can become a high-earning industry with high performance if they have the ability to compete.

Limitations - This research is limited in scope with regard to its approach to resources. The institutional study is only viewed from the angle of cooperatives, which are one of various forms of non-market management.

Originality - The novelty of this research lies in the discovery of the role of cooperatives in supporting the competitiveness of SMEs.

Keywords - competitive excellence, market capacity, financial capacity, technological and innovative capacities, access to resources, cooperatives i srednjih poduzeća za proizvodnju batika u središnjoj Javi u Indoneziji. Prikupljanje podataka provedeno je metodom fokus grupe. Za obogaćivanje analize korišteni su sekundarni podaci. Kako bi se ispunio predloženi cilj istraživanja, predloženi je model ispitan kvantitativnom empirijskom analizom.

Rezultati i implikacije - Rezultat istraživanja pokazuje da poslovni razmjeri, kapaciteti pristupa tržištu i financijski kapaciteti utječu na razinu konkurentnosti malih i srednjih poduzeća proizvođača batika. Nadalje, zadruge mogu pomoći jačanju tržišnih i financijskih kapaciteta te konkurentnosti malih i srednjih poduzeća, iako one nisu učinkovite $u$ jačanju njihovih tehnoloških i inovativnih kapaciteta. Istraživanje pokazuje da mala i srednja poduzeća u industriji batika mogu postati industrije visoke učinkovitosti ako imaju sposobnost međusobnog konkuriranja.

Ograničenja - Istraživanje ima određena ograničenja u pogledu opsega koji se koristi za pristup resursima iz perspektive kapaciteta poduzeća. Istraživanje daje pogled iz perspektive zadruga kao jednog od oblika netržišnog menadžmenta.

Doprinos - ovog istraživanja jest u otkrivanju uloge zadruga u podupiranju konkurentnosti malih i srednjih poduzeća.

Ključne riječi - konkurentska izvrsnost, kapacitet tržišta, financijski kapacitet, tehnološki i inovacijski kapacitetima, pristup resursima, zadruge 


\section{INTRODUCTION}

The development of information technology has become the impetus for a new era of creative industries (Moore, 2014: p. 739). The United Nations Conference on Trade and Development - UNCTAD (2008: p. 4) explained that creative economy emerged as a concept combining creativity, culture, economy, and technology in a contemporary world dominated by visuals, sounds, texts, and symbols. Nowadays, creative industries are one of the most dynamic sectors of the world economy, providing new opportunities for economic growth in developing countries. According to a report of United Nations Educational, Scientific and Cultural Organization - UNESCO (2015), the income from the sector of Cultural and Creative Industries (CCls) all over the world has exceeded that of the telecommunications sector (USD 1,570 billion globally) and has surpassed the Gross Domestic Product (GDP) of India (USD 1,900 billion). The CCI sector has created 29.5 million jobs or has employed $1 \%$ of the world's population.

Bank Indonesia (2017) reported that the creative industries grew $5.6 \%$ and contributed $7.1 \%$ to the country's GDP from 2010 to 2016. Moreover, the creative industries contributed $6.1 \%$ towards export value and employed $10.7 \%$ of the total workforce. The results of the mapping analysis performed by Bank Indonesia in cooperation with the World Bank on five sectors of microand small-scale creative industries indicated that almost every province in Indonesia had a potential for craft and fashion industries. Both sectors had higher competitiveness than the other sectors of the creative industries. According to the statistical data of 2015, the population of Central Java amounts to 39.3 million. About 480,508 people work in 9,342 SMEs (Indonesian Central Bureau of Statistics, 2016b). In Indonesia, SMEs fall into four categories based on their activities, namely, production (non-agriculture), agriculture, trade, and services. Based on the abovementioned data on SMEs, they quantitatively have very high potential for development. However, it turns out that they currently face structural and cultural issues (Kristiansen, 2002; Kristiansen, 2003b; Kristiansen, Furuholt \& Wahid, 2003; Kristiansen \& Indarti, 2004), one of which is the lack of competitiveness in the long term (Storey, 1994; Kolvereid, 1996).

The low economic scale of SMEs' business imposes limitations on (1) access to information and markets / limited capital and efficiency for taking part in industrial exhibitions (Mazzarol, Volery, Doss \& Thein, 1999; Gibbons \& O'Connor, 2003); (2) access to financial resources (Committee of Donor Agencies for Small Enterprise Development - CDASED, 1999; McMahon, 2001); and (3) access to technology and innovation, so that they lack the ability to compete in local, regional and global markets (Gundry, Kickul, Welsch \& Posig, 2003; Swierczek \& Ha, 2003). SMEs also have to gain access to knowledge and innovation for developing dynamic competitive designs while also understand quality control and environmental issues, such as eco-design and labeling, in addition to possessing technical and managerial skills like entrepreneurship, management, accountancy, and marketing (Chaston, 1992; Cromie, 2000; Charney \& Libecap, 2000; Huggins, 2000; Duh, 2003; Kristiansen, 2003a; Suharno, Susilowati, Anggoro \& Gunanto, 2017). SMEs have to pay more attention to non-pricing elements of competition, such as product quality, uniqueness of design, the standardization of motifs, and the distribution of products on time (Reynolds, Hay, Bygrave, Camp \& Autio, 2000; Reynolds, Day \& Lancaster, 2001).

Batik, as part of the craft and fashion industries, is one of the leading products of the creative industries based on local uniqueness in Central Java in the free market era. Batik SMEs achieve an average annual growth of $67 \%$, of which $80 \%$ in the domestic market and $20 \%$ in the export market. They have the potential of supporting economic growth and workforce absorption. According to UNESCO (2015: p. 2), Batik is dyed by proud craftspeople who draw designs on fabric using dots and lines of hot wax, which resists vegetable and other dyes and therefore

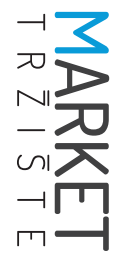




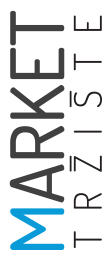

allows the artisan to color the cloth selectively by soaking it in one color, removing the wax with boiling water, and repeating if multiple colors are desired. The wide diversity of patterns reflects a variety of influences, ranging from $\mathrm{Ar}$ abic calligraphy, European bouquets, and Chinese phoenixes to Japanese cherry blossoms and Indian or Persian peacocks. Often handed down within families for generations, the craft of batik is intertwined with the cultural identity of the Indonesian people and, through the symbolic meanings of its colors and designs, expresses their creativity and spirituality.

Nevertheless, research by Bank Indonesia (2016) reveals that SMEs are still facing several problems, namely a lack of market capacity and financial capacity, as well as poor access to technology and innovation in entering business competition. Businessmen in craft industries face three main obstacles: (1) limited access to information and markets (this happens because the entrepreneurs have not determined clear target markets yet and are only oriented towards domestic markets due to limited capacity for production); (2) limited access to financing due to limited security, their limited skill at preparing financial reports, and limited training for employees in financial management; and (3) insufficient access to technology and innovation because the entrepreneurs have limited skills, knowledge, and technology and have not set up specific divisions for the research and development of their products yet. These issues make the entrepreneurs of SMEs unable to optimize their creativity and innovation, so the production process tends to be done traditionally. The entrepreneurs of batik SMEs face the same problems. Therefore, batik SMEs in Central Java have to develop a capacity for expanding markets through networks on a global scale, as well as technological and innovative capacities because industrial environments, consumer tastes, and lifestyle change dynamically with the passing of time.

Most of the batik businesses in Indonesia are still dominated by micro-, small- and medium-sized enterprises (MSMEs) that have the advantage of organizational flexibility in response to environmental changes. Nonetheless, the small size of batik MSMEs causes them to (1) lack efficiency in the economic scale, paying relatively high costs for access to information and expanding markets; (2) have limited access to finance; (3) have no capacity for using technology and innovation. A survey by Bank Indonesia (2016) indicates that SMEs in the creative industries sector, especially batik industries, face a number of obstacles. Including no information on market opportunities, high transaction costs emerging in accessing infrastructures, quality standards, and a lack of skills and knowledge in dealing with customers both in domestic markets and export markets.

Free trade opens up opportunities for competition. Nevertheless, batik SMEs have difficulties competing because of limited economic scale and access to resources (EIM Business \& Policy Research; 1999). The theory of new institutional economics (NIE) (Royer, Bijman \& Bitzer, 2016) suggests that SMEs can cooperate to achieve mutual governance in accessing resources (raw materials, information, markets, finance, technology, innovation, and design), and to increase economic scale to be more competitive in the free trade era. Despite a number of empirical studies that have been conducted (Lieberman \& Dhawan, 2005; Mahendra, Zuhdi \& Muyanto, 2015; Zhu, Wittmann \& Peng, 2012; Singh, 2008; Petrovic \& Milos, 2011), business practices of SMEs, particularly in developing countries, have not become effective yet. This research is an empirical study that analyzes the resourceand institution-based competitive advantage of batik SMEs by improving the market capacity, financial capacity, and technological and innovative capacities of batik SMEs in Central Java, Indonesia.

The research problem is how to develop the ability- and institution-based competitive advantage of batik SMEs in Central Java, Indonesia. The aims of this research are twofold: (1) to analyze the influences of market capacity, financial 
capacity, and technological and innovative capacities on the competitive advantage of batik SMEs in Central Java, Indonesia; and (2) to analyze the role of cooperatives in strengthening the influence of entrepreneurial skills in market and financial capacities on the competitive advantage of batik SMEs in Central Java, Indonesia.

This paper is organized into five sections. The next section discusses the literature related to competitive advantage, the capacity of an SME's management, resource- and institutional-based management, and the hypotheses of the study. Methodology, including the sampling, data collection techniques, and measurement methods, is discussed in section 3. Research findings are then presented in the results section, which is followed by implications and recommendations.

\section{LITERATURE REVIEW}

\subsection{The competitive advantage of a firm}

According to Smith in The Wealth of Nations (1776), a free market offers an incentive for competition that encourages the allocation of factors of production to the most valuable and efficient use. Competition is the act of competing between sellers who equally endeavor to make a profit, to acquire market share, and to increase the number of sales. The theory of classical economics (Smith, 1776) suggests that public policies are shaped by market mechanisms, individualization of welfare, commodification, and minimization of the role of the state. Competition encourages commercial companies to develop products, technology, and services, with the result that they have more options, sell better products, and set lower prices. Based on market mechanisms, market imbalances provide economic opportunities (Kirzner, 2015), but when markets are static, entrepreneurs come up with innovations to create new opportunities and to achieve growth (Schumpeter, 1934), so that a free market also offers incentives for innovative activities.
Competitive advantage is the ability that is acquired through the characteristics and resources of a company to deliver a higher performance compared to that of other companies in the same industry or markets (Porter, 2008). Several studies (Lieberman \& Dhawan, 2005; Chen, Delmas \& Lieberman, 2015) use efficiency as the measurement of competitive advantage that will be achieved if the company can optimize output or efficiency (differentiation strategy) or minimize input (cost leading strategy), as illustrated in the production function as follows:

$$
Q=A K^{\alpha} L^{1-a}
$$

where $\mathrm{Q}$ represents the output or production result, which is a function of technology index $(A)$, capital (K), and workforce (L). The symbol a refers to model parameter. For the value of technology, the index is the so-called efficiency parameter. Production is defined as value-added $(Y)$ with the function of technology level $(A)$, workforce (L) and capital (K):

$$
Y=f(A, L, K)
$$

The challenge of such a traditional approach is conceptually the production function to spend expense encountered by an effective company that occupies the best practical method within. Most companies are not fully efficient in capitalizing the resource inputs. Therefore, the related companies posit below the average industries. The advancement of econometrics by Aigner, Lovell and Schmidt (1973) in Suharno, Susilowati and Firmansyah (2017) results from the model development of stochastic frontier production capable of identifying the production axis and the company's relative position.

$$
\begin{gathered}
Y=f(L, K) T E(Z) \\
T E=\frac{d \pi r}{d \pi k}
\end{gathered}
$$

where: TE = technical efficiency, the function of efficiency increased (competitive advantage), $\mathrm{Z}=$ error variable, $\mathrm{d} \pi \mathrm{r}=$ efficiency advantages,

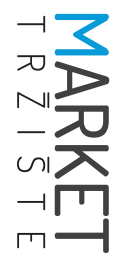




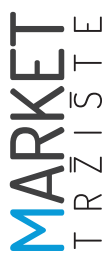

$\mathrm{d} \pi \mathrm{k}=$ resources spent to improve competitive advantages. Formula (3) can be written in the natural logarithm of the empirical model as follows:

$\operatorname{Ln} Y_{i t}=\beta_{0}+\beta_{1} \operatorname{Ln} L_{i t}+\beta_{2} \operatorname{Ln} K_{i t}+u-v$

where: $Y_{i t}=$ value-added of firm $i$ at time $t, L_{i t}=$ workforce of firm $i$ at time $t, K_{i t}=$ capital of firm $i$ at time $t, u$ is the variable of explainable error such as entrepreneurs activities, whereas $v$ is the unexplainable error variable. The efficiency stochastic frontier approach above has weaknesses because it has only one dependent variable. The data envelopment analysis (DEA) approach (Lieberman \& Dhawan, 2005; Chen et al., 2015), which is part of the development of the efficiency stochastic frontier, is an analysis program that uses a non-parametric approach. The advantage of DEA is its capability to use several output variables.

In an SME, most of the entrepreneur's constraints and opportunities in managing intangible resources, such as market access capacity (MAR), financial access capacity (FIN), but also technology and innovation access capacity (INOV), possibly affect efficiency (TE). Furthermore, the it symbol can be explained as firm $i$ at time $t$.

$$
\mathrm{TE}_{i t}=\gamma_{0}+\gamma_{1} \mathrm{MAR}_{i t}+\gamma_{2} \mathrm{FIN}_{i t}+\gamma_{3} \mathrm{INOV}_{i t}+v
$$

where: $\gamma_{0}=$ constant, $\gamma_{1}=$ coefficient of MAR, $\gamma_{2}$ $=$ coefficient of FIN, $\gamma_{3}$ coefficient of INOV, and $v$ is the unexplainable error variable.

\subsection{The capacity of an SME's management}

The resource-based view (RBV) (Barney, 1991) becomes one of the strategies to achieve sustained competitive advantages that emphasize a company's internal resources. The perspective of Industrial organization (Porter, 2008) assumes that competitive advantages are defined by a company's external factor i.e. the industry's attractiveness. However, resources are not necessarily homogenous. There is possibly heteroge- neity of resources and non-dynamic company resource movement in one industry.

In the creative industry sector, it is necessary for companies to have valuable, unique, original, and sustainable resources. Akio (2005: p. 126) classifies the main resources as follows: unique product, expertise, special production methods, connection, location, flexibility. Meanwhile, the critical resources include competencies, capabilities, and knowledge (Nunally, 1978; Ryan, 1970; Sinha, 1996). Nonetheless, SMEs face many challenges in the areas of market capacity, financial capacity, technical capacity, and innovation on their path towards competitiveness in the longer term (Verhees \& Meulenberg, 2004).

Milen and World Health Organization (2001: 354) define capacity as "individual capabilities, organization or system to run the intended function efficiently, effectively, and respectively". According to Hilton, Maher and Selto (2003: p. 217), capacity is the measurement of a process's capabilities to transform resources into specific outputs. Capacity does not merely cover technical competency, or available financial resources or sufficient materials. The concept of capacity involves volume/resource management flow (tangibles/intangibles), such as input that is applied and spent to produce a certain output.

In this case, capacity relates to individual capabilities, organization, or system to execute functions and to meet the objectives effectively and efficiently. From an entrepreneurship perspective, capacity in this research refers to entrepreneurship resource capacity (management) beyond the other resources (tangible and intangible assets) to achieve the organization's vision. In SMEs, the factors of management are performed by managers that are consecutive as business owners (Yuan \& Vinig, 2007: p. 32).

According to Storey (1994), there are three main elements to improve the capacity of SMEs: characteristics of the entrepreneurs, characteristics of the SMEs, and type of strategy associated with growth. Likewise, at the APEC summit in Ottawa in September 1997, Harvie (2004: p. 14- 
17) mentioned five main elements to improve the capacity of SMEs, including market, financial, technology, human resources, funding, and information. This research works on three main capacities of SMEs, namely market, financial, and innovation and technology:

1. Market capacity. SMEs encounter certain issues specifically related to the scope and in the context of rapid trading liberalization. They need to develop their capacity to capitalize opportunities that appear as the effect of the open regional trading system.

2. Financial access capacity. The opportunities to access some funding can be an important capital for the small-scale enterprise to gain access to required resources. Many SMEs are not quite concerned with financial resources. The programs from commercial banks, other private sectors, and government funding are difficult to define and articulate in terms of the financial needs of SMEs. The financial institution must be responsive to their needs and strive to simplify the trading documentation.

3. Technology and innovation capacity. In the scope of a knowledge-based economy, the application of information communication technology (ICT) will be the bridge for SMEs. When SMEs have limited access and limited understanding of technology, their prospects of utilizing such potentials will be lower. An active role assumed by local government is needed (in the focus of infrastructure renovation, funding, and training, but also as a source of information on business opportunities).

Based on the explanations above, the following hypotheses can be formulated:

H1a. Market capacity positively affects the competitive advantage of batik SMEs.

H1b. Financial capacity positively affects the competitive advantage of batik SMEs.

H1c. Technology and innovation capacity positively affects the competitive advantage of batik SMEs.

\subsection{Institutional-based management}

New Institutional Economics (NIE) offers itself as the developer of the theory of non-market institutions on the basis of the neoclassical economic theory. Coase (1937) emphasizes institutional benefits, mainly the efficiency of transaction expenses. The theory of collective action, as a branch of NIE (Olson, 1971), highlights the importance of collective action in achieving efficiency of resources and economic performance management. According to Williamson (2000), NIE operates on two levels: institutional environment (the macro level) and institutional arrangement (the micro level). Institutional environment functions as a set of political, social, and legal regulation structures that organizes production activities, exchange, and distribution (Bandura, 1977; Aldrich \& Zimmer, 1986; Kristiansen, 2004; Pajares, 2002). On the other hand, the micro-analysis level focuses on the issue of institutions of governance (Steel, 1994; Meier \& Pilgrim, 1994; Mulhern, 1996; Mead \& Liedholm, 1998).

The scale of the economy places limitations on SMEs (such as the lack of capital and efficiency to take part in the exhibition of the industry) in accessing markets, as well as in the accessing resources (finance, technology, and innovation). Thus, they will be hindered in their ability to compete in local and global markets. On the basis of the NIE theory (Coase, 1937; North, 1991; Williamson, 2000), SMEs will work significantly through vertical alliances (in the commodity value cycle) and horizontal alliances (among similar business groups) to increase their economic scale. In order to access markets or control competition, it is crucial for the batik industry to adopt a global perspective through strategic partnerships in national or international markets. For example, SMEs can develop strategic alliances with foreign distributors as a strategy to access new markets and simultaneously improve their product quality. SMEs may also cooperate with a cluster (such as a centralized business group in a certain geographic lo- 


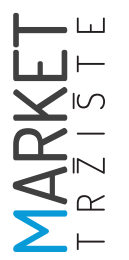

cation focusing on similar industries in the same sector) to facilitate access to information and markets, capital, knowledge and technology, innovation, training, and employee development (ESCAP, 2009: 212).

The conjunction of entrepreneurs of batik SMEs through a vertical alliance and a group of businesses in the batik SME cluster can be explained through the concept of cooperation (cooperatives) by optimizing their potentials to save transaction costs and developing what has been described as countervailing power (Alston \& Gillespie, 1989; Singh, 2008; Petrovic \& Milos, 2011; Huang \& Cao, 2015): (a) higher selling price - this is presumably the most important benefit from the advent of manufacturer conjunction; (b) economic scale - taking collective action on the same timeline will save certain expenses or improve efficiency in a certain process; (c) external economies provide advantages including the improvement of member productivity due to information distribution; (d) non-economic advantages - the cooperative movement places significant emphasis on non-economic advantages. The condition of perfect competition is the existence of an equal number of sellers and buyers, and both act as price makers.

Many developing countries are characterized by weak governance environment, limited availability of information, high costs of coordination, and high risk (Dorward, Poole, Morrison, Kydd \& Urey, 2003). The lack of physical infrastructure significantly increases transaction costs and becomes a challenge for production and marketing (Barrett, 2008). Besides the weak institution environment, SMEs face challenges in terms of access to input and output markets, access to information and credit facilities, and assistance with technical innovation. The access is very limited because of the improper function of markets and scarce market information. The term "institutional challenges" emphasizes that the solution to the challenges faced by batik entrepreneurs cannot be resolved by an individual action but requires several collective actions (Royer et al., 2016). From the input point of view, such challenges relate to the lack of resource access, financial aid, and technology access. From the output perspective, the lack of market information, quality, and inspection control, the connection to output market becomes one of the main institutional challenges. The lack of horizontal organization (between producers) relates to both input and output aspects of markets.

Royer and others (2016) explain several institutional strategies to reinforce the value cycle, namely the contract system, partnership, and producer organization. Such contract system, partnership, and producer organization have been practiced in reinforcing the institution of SMEs. Each setting has mitigated institutional challenges by creating the market network (e.g., by connecting buyers and manufacturers, helping negotiation, giving information on quality requirements, etc.), preparing training and technical assistance, supporting institution development, and certification.

Based on the above, we can hypothesize that:

H2a. Cooperatives positively affect the competitive advantages of batik SMEs.

H2b. Cooperatives that moderate the effects of entrepreneurial capabilities of batik SMEs to access markets positively affect the competitive advantages.

H2c. Cooperatives that moderate the effects of entrepreneurial capabilities of batik SMEs to access financial resources positively affect the competitive advantages of batik SMEs.

$\mathrm{H} 2 \mathrm{~d}$. Cooperatives that moderate the effects of entrepreneurial capabilities of batik SMEs to access technology and innovation positively affect the competitive advantages of batik SMEs.

\section{RESEARCH METHODOLOGY}

The research population in this study consists of batik SMEs in Central Java, and the sampling strategy applied a two-stage (multi-stage) sampling. The first stage was conducted by taking a local 
sample in three districts of batik SMEs in Central Java, Indonesia: Surakarta, Pekalongan and Rembang. Batik SMEs in Surakarta district are representative of the Kraton (palace) batik in Central Java. Meanwhile, batik SMEs in Pekalongan district and Lasemown coastal batik have grown out of and collaborate with the culture of Islam and China. The second-stage sampling of SMEs used simple a random sampling method because the population tends to be homogenous. The survey, conducted in 2016, covered 100 batik SMEs in Surakarta, Pekalongan, and Rembang districts. Based on the number of employees, an industry in Indonesia can be divided into four categories (Indonesian Central Bureau of Statistics, 2016a; 2016b):
a) home industry, an industry with 1-4 em- ployees;
b) small industry, an industry with 5-19 em- ployees;
c) medium industry, an industry with 20-99 employees;
d) large industry, an industry with 100 or more employees.

Competitive advantages are measured by comparing company efficiency with an industrial average that comes from DEA efficiency (Lieberman \& Dhawan, 2005; Shi, Takala, Muhos, Poikkimaki \& Chen, 2013; Chen et al., 2015). A company will have higher competitive advantages compared to the competitor average if it possesses comparable output, with input in the production and income function that is more efficient (higher) than that of its competitor. Input variable in this research includes labor cost, material, and fixed cost. Output variable in this research are measured by batik production and sales.

The research aim was to understand the level of SME efficiency that can be defined as a ratio of total weighted output and total weighted input. The efficiency value is the input-to-output ratio, and its varied between 0 and 1 (0\%-100\%). The stages of measurement of the efficiency value using DEA method areas are the following:

1. determining decision-making unit (DMU);

2. determining input and output variables;
3. doing the analysis to obtain relative efficiency value using the constant return to scale (CRS) approach. The DEA of the CRS model is an efficiency measurement for each DMU as a maximum ratio between worth output and input. Each worth value that is used in the ratio is determined by a constraints that the same ratio for each DMU must have a value less than or equal to one.

The mathematical formula for the CRS model DEA can be defined as follows:

To maximize the $K_{\text {th }}$ DMU:

$$
E_{k}=\sum_{r=1}^{s} U_{r k} * Y_{r k}
$$

With constraints or challenges:

$$
\left(\sum_{r=1}^{s} U_{r k} * Y_{r j}\right)-\left(\sum_{i=1}^{m} V_{i k} * X_{i j}\right) \leq 0 ;
$$

$j=1,2, \ldots, n$

$\sum_{i=1}^{m} V_{i k} * X_{i k}=1$

$U_{r k} \geq 0 ; r=1,2, \ldots, S$

$V_{i k} \geq 0 ; i=1,2, \ldots, m$

The first inequality indicates that the efficiency ratio for the other DMU is no more than 1, while the second equation is positively weighted. Where:

$Y_{r j}=$ the amount of output $r$ produced by $j$ th batik SME

$X_{i j}=$ the amount of input $i$ required by jth batik SME

$s=$ the number of outputs generated by batik SMEs

$m=$ the number of inputs used by batik SMEs

$U_{r k}=$ weighted worth of output $r$ produced by kth batik SME

$V_{i k}=$ weighted worth of input $i$ required by $k t h$ batik SME.

Batik SME's $E_{k}=$ the value used as an indicator of relative efficiency by $k$ th batik $S M E ; k=$ batik SME index: in our research $k=1,2, \ldots, 100$

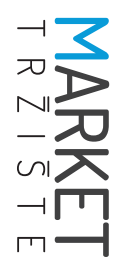

$(7)$ 
The above mathematical formula is analyzed by using DEAP Version 2.1 software. The value of relative efficiency obtained from the CRS model DEA is approximately between $0 \%$ and $100 \%$.
A batik SME is technically perceived as having a more efficient performance if this value is close to $1(100 \%)$ and will be more inefficient if it shifts towards 0 (0\%).

\section{TABLE 1: Variable and operational definition}

\begin{tabular}{|c|c|c|}
\hline Variable & Variable Operational Definition & Reference \\
\hline $\begin{array}{l}\text { Competitive } \\
\text { advantage (CA) }\end{array}$ & $\begin{array}{l}\text { The firm's efficiency compared with average industries, calculated by } \\
\text { DEA efficiency } \\
\text { Output } \\
\text { Production volume = average production number per year (unit) } \\
\text { Income = average selling volume per year (Rp) } \\
\text { Input } \\
\text { Labor cost = average amount of labor cost per year (Rp) as the } \\
\text { multiplication between wages and the number of employees } \\
\text { Cost of raw materials = average amount of raw material cost per } \\
\text { year (Rp) as the multiplication between the cost of raw materials } \\
\text { and the number of raw materials } \\
\text { Fixed cost = the cost for fixed expenses of the firm disregarding the } \\
\text { value of production }\end{array}$ & $\begin{array}{l}\text { Lieberman \& } \\
\text { Dhawan (2005); } \\
\text { Shi et al. (2013); } \\
\text { Chen et al. } \\
\text { (2015) }\end{array}$ \\
\hline \multicolumn{3}{|c|}{ Resource-based approach } \\
\hline $\begin{array}{l}\text { Dummy of market } \\
\text { access capacity } \\
\text { (DMAR) }\end{array}$ & $\begin{array}{l}\text { Total availability of information and market access: a) direct market } \\
\text { access (excluding middlemen), b) possessing pricing negotiation } \\
\text { skills to buyers, c) possessing pricing negotiation skills to suppliers. } \\
\text { (0=there are three challenges, } 1=\text { there are two of three challenges, } \\
2=\text { there is one of three challenges, } 3=\text { easy/no market challenges) }\end{array}$ & $\begin{array}{l}\text { Munir, Lim \& } \\
\text { Knight (2014); } \\
\text { Mahendra et al. } \\
\text { (2015); Zhu et al. } \\
\text { (2012) }\end{array}$ \\
\hline $\begin{array}{l}\text { Dummy of financial } \\
\text { access capacity } \\
\text { (DFIN) }\end{array}$ & $\begin{array}{l}\text { Total availability in accessing financial resources: a) no challenges } \\
\text { related to capital, b) no collaterals, c) proper financial reports. } \\
(0=\text { there are three financial challenges: } 1=\text { there are two of three } \\
\text { financial challenges } 2=\text { there is one of three financial challenges, } \\
3=\text { easy/no financial challenges) }\end{array}$ & \\
\hline $\begin{array}{l}\text { Dummy of } \\
\text { technological } \\
\text { and innovative *) } \\
\text { capacity (DINOV) } \\
\text { Institutional-based }\end{array}$ & $\begin{array}{l}\text { Total access to technology, product, and process innovation ( } 0=\text { no } \\
\text { access of technology, process, and product innovation, } 1=\text { there is } \\
\text { one of three access, } 2=\text { two of three access, } 3=\text { three access). }\end{array}$ & \\
\hline $\begin{array}{l}\text { Dummy of CO- } \\
\text { operative (DGROUP) }\end{array}$ & $\begin{array}{l}\text { Total cooperative type held: the involvement of coo } \\
\text { business groups ( } \mathrm{No}=0, \mathrm{Yes}=1 \text { ), private/state partner } \\
\text { agreement contract, supplier agreement contract }\end{array}$ & $\begin{array}{l}\text { Ferreira } \\
\text { des }\end{array}$ \\
\hline \multicolumn{3}{|l|}{ Control variable } \\
\hline $\begin{array}{l}\text { Dummy of type } \\
\text { (DTYPE) } \\
\text { Dummy of export } \\
\text { (DEXP) } \\
\text { Dummy of region } \\
\text { (DREGION) }\end{array}$ & $\begin{array}{l}\text { Business scale ( } 0=\text { micro business, fewer than } 10 \text { employees, } 1=\text { small } \\
\text { business, } 10-49 \text { employees, } 2=\text { =medium-sized business, } 50-100 \\
\text { employees) } \\
\text { Technology adoption ( } 0=\text { printing batik, } 1=\text { handmade) } \\
\text { Export market access ( } 0=\text { local only, } 1=\text { the export markets) }\end{array}$ & $\begin{array}{l}\text { Marsden } \\
\text { (1992); Singh \& } \\
\text { Krishna (1994); } \\
\text { Smallbone, Leig } \\
\text { \& North (1995); } \\
\text { Mazzarol \& Choo } \\
\text { (2003) }\end{array}$ \\
\hline
\end{tabular}

Note: * Technology is the collection of techniques, skills, methods, and processes used in the production of goods or services. Innovation can be defined simply as a "new idea, device or method" on process and product. 


\subsection{Regression model measurement}

The factors of intangible assets that affect the competitive advantage (CA) of batik SMEs are overviewed from the dummy of market capacity (DMAR), dummy of financial capacity (DFIN), and dummy of technological and innovative capacity (DINOV). The factors that affect the competitive advantage of batik SMEs are analyzed by using the technique of regression analysis with dummy variables (Galperin, 1985) as in the following formula:

$\mathrm{CA}=\beta_{0}+\beta_{1} \mathrm{DMAR} 1+\beta_{2} \mathrm{DMAR} 2+\beta_{3} \mathrm{DMAR3}$ $+\beta_{4}$ DFIN1 $+\beta_{5}$ DFIN $2+\beta_{6}$ DFIN3 $+\beta_{7}$ DINOV 1 $+\beta_{8}$ DINOV $2+\beta_{9}$ DINOV $3+\beta_{10}$ DGROUP + $\beta_{11}$ DSIZE1 $+\beta_{12}$ DSIZE2 $+\beta_{13}$ DTYPE $+\beta_{14}$ DEXP $+\beta_{15}$ DREGION1 $+\beta_{16}$ DREGION2 $+\varepsilon$

where: $\beta_{0}=$ intercept, $\beta i, i=1,2, \ldots, 16=$ slope, $\varepsilon=$ Error. In addition to the previously mentioned variables (DMAR, DFIN, DINOV), the research model also compares the impact of business groups (DGROUP), business scale (DSIZE), technology adoption (DTYPE), export market access (DEXP), and region (DREGION) on the competitive advantage of batik SMEs.

To accuracy of the regression function with regard to the observation value can be seen from the value of best fit. The goodness of fit is measured using the F statistic and determination coefficient. The determination coeffi- cient $\left(R^{2}\right)$ is used to calculate the percentage of deviation of the dependent variable that is caused by the independent variable. The F-test is a formula significance test that is used to determine how the independent variable affects the dependent variable $(Y)$. The $P$ value is the probability to refute zero hypothesis if the test is presumably correct. The significant level is $1 \%$ (very significant). If the $p$-value is less than the significant level, the researcher can conclude that the observed influence depicts the population characteristic, not only a sampling error.

\section{RESULTS AND DISCUSSION}

\subsection{DEA analysis}

In terms of inputs (Table 2), the highest average cost for batik production is accounted for by labor costs (IDR 20.81 million per month), followed by material costs (IDR 12.10 million), and overhead costs (IDR 3.87 million per month). Batik industry is generally an art and craft (handmade) industry that uses a lot of labor. The material cost consists of raw material and auxiliary cost. Overhead costs for batik SMEs consist of electricity costs, municipal waterworks, telephone costs, and administrative salaries. The average production of batik cloth at batik SMEs is 10 units of batik or 10 pieces/month (2 meters/ piece). The average income from monthly sales is IDR 41.27 million.

TABLE 2: Input variable and DEA output

\begin{tabular}{|l|c|c|c|c|c|}
\hline Parameter & \multicolumn{2}{|c|}{ INPUT } & \multicolumn{3}{c|}{ OUTPUT } \\
\hline & Labor & Material & Overhead & Quantity & Sales \\
\hline Average & 20.81 & 12.10 & 3.87 & 0.04 & 41.27 \\
\hline Standard deviation & 5.32 & 3.47 & 1.28 & 0.01 & 9.59 \\
\hline Minimum & 7.20 & 2.16 & 0.40 & 0.01 & 10.98 \\
\hline Maximum & 33.60 & 15.50 & 6.66 & 0.06 & 61.00 \\
\hline
\end{tabular}

Source: Analysis of responses in the survey of batik business owners (2016) 
From the results of the DEA analysis in Table 3, it can be seen that the efficiency level of batik SMEs ranges between $81.20 \%$ and $100 \%$ (benchmark). The majority of batik SMEs (65\%) have the efficiency level between $81.00 \%$ and $90.00 \%$. The differentiation in efficiency can be caused by the access to resources and the ability to generate the production output and sales (consisting of components of sales volume and price/product value).

TABLE 3: Summary of DEA results of the efficiency level of batik SMEs in Central Java, Indonesia

\begin{tabular}{|l|c|}
\hline Parameter & Value (\%) \\
\hline Efficiency & \\
\hline Average efficiency & $89.41 \%$ \\
\hline Standard deviation efficiency & $5.75 \%$ \\
\hline Minimum efficiency & $81.20 \%$ \\
\hline Maximum efficiency & $100.00 \%$ \\
\hline Frequency & Percent (\%) \\
\hline $91 \%-100 \%$ efficiency & $35.00 \%$ \\
\hline $81 \%-90 \%$ efficiency & $65.0 \%$ \\
\hline Efficiency < $80 \%$ & $0.00 \%$ \\
\hline Total & $100.00 \%$ \\
\hline
\end{tabular}

Source: Analysis of responses in the survey of batik business owners (2016)

It can be seen from Table 3 that the performance of Batik SMEs has an average efficiency rate of $89.41 \%$, or it ranks in the category of efficient because its efficiency rate ranges between $80 \%$ and $100 \%$. This illustrates that the average batik SME has efficient performance.

\subsection{Resource access capacities, cooperative type, and competitive advantage}

The research found that, generally, the SMEs that possess market, financial, technology, and innovation capacity have higher cost efficiency (Table 4). The access to technology and innovation can be perceived from patented products, process quality innovation in production (ISO), and environment management certification. Table 4 shows that SMEs with the access to product and process innovation generally have a higher efficiency than those without product and process innovation. Most batik SMEs (71 \%) do not put much effort into product design innovation. Most production plans are created based on the proposal from distributors (agents and retailers) or export intermediaries. Batik SMEs remain focused on production and production process strategies. The marketing system is typically similar to that employed by former business owners, such as parents. Batik centers do not concern themselves with any aspects that follow the sale itself, such as packing, distribution, or service. Thus, their products are marketed using simple strategies: selling batik to markets or stores or using the mouth-to-mouth promotion system (personal selling) to traditional (local) market segments as the targeted markets. Most batik SMEs in Central Java, Indonesia have not capitalized on the capacity of innovation and technology in either creating or adopting batik design innovation for production and marketing. Business competition in the batik industry is still in the realm of pricing competition, instead of product quality.

The market capacity can be perceived from direct market access without the presence of middlemen, the capabilities to negotiate with suppliers and arrange the selling price, and the ease of promotion. Table 4 highlights that batik SMEs with direct market access possess higher cost efficiency compared to batik SMEs that use middlemen. Batik SMEs with price-making capabilities are characterized by higher cost efficiency compared to those that are price takers. Batik SMEs with bigger market capacity (domestic or global scale) involving the access to participation in exhibitions and information technology access have higher efficiency than batik SMEs lacking access to promotion exhibitions and selling their products to middlemen merchants. 
TABLE 4: Descriptive statistics of resource access capacities and competitive advantage

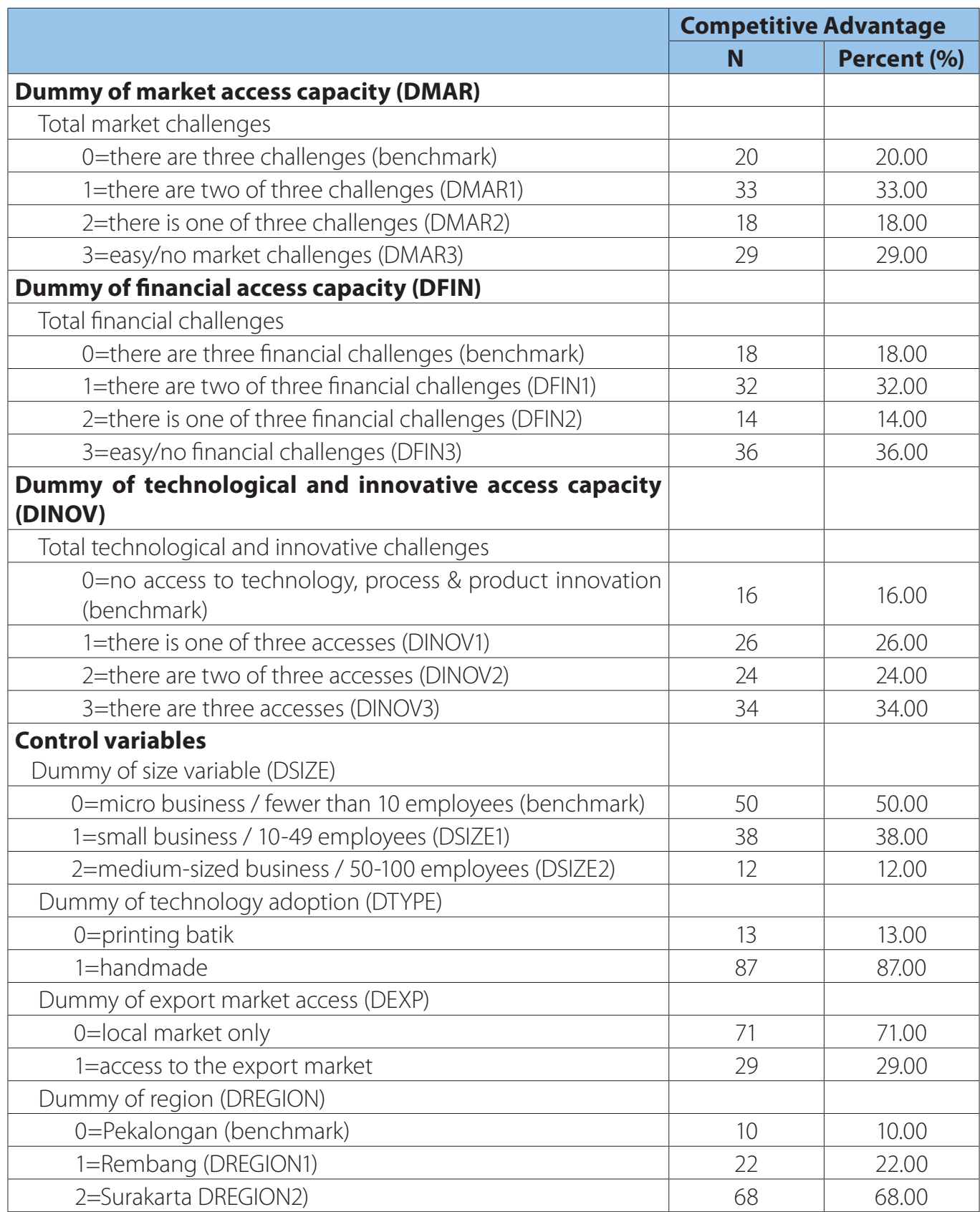

Source: Analysis of responses in the survey of batik business owners (2016)

Financial capacity can be perceived from the perspective of internal capital adequacy or the capabilities to access external sources of capital to meet the production and operational needs, the availability of sufficient collaterals, and the availability of financial reports. Table 4 shows that batik SMEs with adequate internal and capabilities to access external sources of capital to 
meet their production and operational needs, sufficient collaterals, and with available financial reports commonly have higher efficiency.

From the perspective of market capacity, the product distribution of batik SMEs in Central Java surpasses local and domestic markets (71\%) to also encompass international markets (29\%) (Table 4). Their international distribution areas include Malaysia, Singapore, Thailand, India, Italy, French, and the Middle East. Most batik SMEs (50\%) are micro businesses, small businesses (38\%) and only $12 \%$ are medium-sized enterprises. As the majority of them established their business more than 10 years ago, they have actually gathered quite a lot of experience (Table 1). The product types available in markets are based on a variety of batik techniques employed, such as stamping batik, printing batik, handmade batik, and combination batik (stamping and handmade). Table 1 describes the product types that are mostly produced by batik entrepreneurs, that is, printing batik (13\%), while the product type of combination batik (stamping and handmade) is accounted for by the remaining business units surveyed (Table 4).
The majority of batik SMEs (53 \%) have participated in cooperatives (Table 5). Batik SMEs that have once had cooperation with distributors or buyers, or a joint venture in manufacturer cooperatives, as well as those that received a grant of financial aid from the government or private agents, normally have higher efficiency than other SMEs that have few group activities. Participation in manufacturer cooperatives and partnership with the government and private agents are the predominant schemes in which SMEs have been involved. In this research, the connections of batik SMEs as the members of manufacturer cooperatives demonstrate many benefits to support their business, such as determining batik-selling price in order to be more competitive in markets and avoiding the lower pricing competition. Manufacturer cooperatives also provide other advantages, including lower cost in the purchase of raw and basic materials thanks to a large number of group orders from the members of cooperatives. In addition, they provide support in marketing coordination through clusters and aid with regard to aid from the government and private holders. Business contracts with suppliers are beneficial in assur-

TABLE 5: Descriptive statistics of cooperative type and competitive advantage

\begin{tabular}{|l|c|c|}
\hline \multirow{2}{*}{} & \multicolumn{2}{|c|}{ Competitive advantage } \\
\cline { 2 - 3 } & $\mathbf{N}$ & Percent (\%) \\
\hline $\begin{array}{l}\text { Group (DGROUP) } \\
\text { The agreement contracts with suppliers }\end{array}$ & & \\
\hline Available & 100 & 0.00 \\
\hline Not available & & 100.00 \\
\hline The agreement contracts with buyers & 4 & 4.00 \\
\hline Available & 96 & 96.00 \\
\hline Not available & & \\
\hline Manufacturer Organization/Cluster & 54 & 54.00 \\
\hline Available & 46 & 46.00 \\
\hline Not available & & \\
\hline Private/State Partnership & 53 & 53.00 \\
\hline Available & 47 & 47.00 \\
\hline Not available & & \\
\hline
\end{tabular}

Source: Analysis of responses in the survey of batik business owners (2016) 
ing the supply chain stability when it comes to resources (input) such as fabrics and other basic materials. Meanwhile, business contracts with buyers maintain the cycle of demand and production continuity based on a pricing agreement over a long term. However, only few business holders have undertaken to improve their efficiency or secure business contracts with suppliers and buyers.

\subsection{Factors of competitive advantage}

In the era of free trade and associations such as ASEAN Economic Community 2015, any prod- ucts from foreign countries can be a threat to local markets. Many enterprises in a number of sectors, including Indonesian batik manufacturers, can enter business competition in a globalization era. Since 2015, batik SMEs have had to compete with cheaper imported batik in local markets. Besides the challenge of product quality to compete in export markets, they are now under threat in their local markets due to imported products. A summary of results of a test analysis of regression factors for competitive advantages of batik SMEs is provided in Table 6.

TABLE 6: Regression results

\begin{tabular}{|c|c|c|c|}
\hline & \multicolumn{3}{|c|}{ Competitive advantage (CA) } \\
\hline & & B & $\rho$ \\
\hline (Constant) & $\beta_{0}$ & 83.048 & $* * *) 0.000$ \\
\hline \multicolumn{4}{|c|}{ Independent variable } \\
\hline DMAR1 & $\beta_{1}$ & 0.848 & 0.277 \\
\hline DMAR2 & $\beta_{2}$ & 2.390 & ***) 0.007 \\
\hline DMAR3 & $\beta_{3}$ & 2.434 & $* * *) 0.004$ \\
\hline DFIN1 & $\beta_{4}$ & 1.494 & 0.117 \\
\hline DFIN2 & $\beta_{5}$ & 1.080 & 0.241 \\
\hline DFIN3 & $\beta_{6}^{3}$ & 2.868 & $* * *) 0.002$ \\
\hline DINOV1 & $\beta_{7}^{0}$ & 0.880 & 0.263 \\
\hline DINOV2 & $\beta_{8}$ & 0.655 & 0.390 \\
\hline DINOV3 & $\beta_{9}^{8}$ & 1.352 & 0.111 \\
\hline DGROUP & $\beta_{10}$ & 0.826 & 0.200 \\
\hline \multicolumn{4}{|c|}{ Control variable } \\
\hline DSIZE1 & $\beta_{11}$ & 4.698 & $* * *) 0.000$ \\
\hline DSIZE2 & $\beta_{12}$ & 9.879 & ***) 0.000 \\
\hline DTYPE & $\beta_{13}$ & -0.486 & 0.488 \\
\hline DEXP & $\beta_{14}$ & 0.443 & 0.431 \\
\hline DREGION1 & $\beta_{15}$ & -0.532 & 0.494 \\
\hline DREGION2 & $\beta_{16}$ & -0.742 & 0.374 \\
\hline R-squared & & 0.930 & \\
\hline F-statistic & & 69.311 & \\
\hline Prob (F-statistic) & & 0.000 & \\
\hline
\end{tabular}

Description: ${ }^{* *}$ significant impact with error tolerance of $1 \%$. 


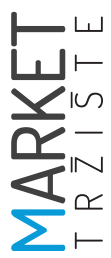

The results of regression analysis for competitive advantages of batik SMEs, as illustrated in Table 6 , show the value of $\mathrm{R}^{2}$ at 0.930 or $93.0 \%$. It means that all independent variables in this research are capable of explaining the change variation: the increase or the decrease of the dependent variable (competitive advantages) of $93.0 \%$. The remaining portion of $7.0 \%$ appears not to be affected by other variables that are not mentioned in this research model. The result of data analysis in Table 6 highlights 5 (five) factors that affect considerably the competitive advantages of batik SMEs in Central Java, Indonesia. These are: business scale (DSIZE1 and DSIZE2), market access capacity (DMAR2 and DMAR3), and financial access (DFIN3). The constant's value is 83.048 , that is, without independent variable, the average value of competitive advantages of batik SMEs in Central Java is 0.83 $\%$. Thus, the scale of business affects their competitive advantages.

The business scale (DSIZE1 and DSIZE2) has been shown to affect positively the competitive advantages of batik SMEs in Central Java, Indonesia. The value of regression coefficients $(\beta)$ is 4.698 and 9.879 , respectively $(\rho<.01)$. It means that the micro business' scale differs from that of small (DSIZE1) and medium-sized businesses (DSIZE2). The competitive advantage of medium-sized batik SMEs (DSIZE2) is significantly higher at 9.879 than that of micro businesses. The competitive advantages of small batik SMEs in Central Java (DSIZE1) at 4.698 differs significantly from those of micro businesses. The bigger scale of business will provide efficiency to the economy of scale, so it will improve the cost efficiency for competitive advantages of batik SMEs in Central Java, Indonesia. By contrast, the smaller scale of business will challenge the efficiency of the economy of scale during production, operational and marketing activities, so it will reduce the cost efficiency necessary to compete in local, domestic, or global markets. The economy of scale gives a contribution to SMEs in their access to markets (due to the lack of capital and efficiency to take part in industry exhibitions), a challenge in accessing the financial resources, so it will foster competition in local and global markets. Based on the NIE theory (Coase, 1937), SMEs can have an agreement through vertical alliances (in the commodity value cycle) and horizontal alliances (among similar business units) to develop their economy of scale. In order to access markets and control competition, it is important for the batik industry to adopt a global perspective through strategic partnerships, either in the domestic or in foreign markets (Akhtar, 1997). Batik SMEs can create a strategic alliance with foreign distributors as a method of access to new markets and can subsequently improve their product quality. They can have cooperation in the cluster to facilitate access to information and markets, capital, technology and knowledge, innovation, training, and employee development (ESCAP, 2009).

The market capacity (DMAR2 and DMAR3) was also found to affect positively the competitive advantages of batik SMEs in Central Java, Indonesia. The value of the regression coefficient $(\beta)$ is 2.390 and 2.434 , respectively $(\rho<.01)$. It means that three challenges differ from one of the three challenges (DMAR2) and from easy or market challenges at all (DMAR3). The competitive advantage of batik SMEs with easy business challenges with regard to the market (DMAR3) is significantly higher at 2.434 from that of the SMEs coping with three challenges. The competitive advantage of batik SMEs facing one of the three challenges (DMAR2) at 2.390 differed significantly from those experiencing three challenges in Central Java. Many batik SMEs focus on production instead of direct market access. This issue mostly causes them to have a lower bargaining position toward middlemen, stores, buyers, and other distributor channels or other agents with direct access to markets. As a result, business owners develop a business process with little production and efficiency. Consequently, their competitive advantages are low. Low efficiency describes a process in which the return of the business is not equal to its production business cost, but only covers the production cost. Harvie (2004) explains that the challenge of SMEs relates to the high cost of 
access and use of information technology. The activity of the manager-owner in accessing information and the market through promotion activities improves the cost (input), while potentially increasing the sales (output). As micro and small enterprises, batik SMEs in Central Java, Indonesia generally do not have a specific division that works on market research to observe and analyze the factors that affect consumer needs and preferences. As most of them have known their customers for a long time, the needs of customers are observed and evaluated through product development and consistent service delivery. The capabilities of the manager-owner of batik SMEs in determining pricing in order to create valuable products for customers will also increase the selling price and improve efficiency. That scenario shows potential in developing the competitive advantages of SMEs for competition in the markets.

The financial access capacity (DFIN3) has also been proven to affect positively the competitive advantages of batik SMEs in Central Java. The value of the regression coefficient $(\beta)$ of $2.868(\rho<.01)$ means that three financial challenges differ from easy or no financial challenges (DFIN3). The competitive advantage of batik SMEs with easy financial challenges in their business (DFIN3) at 2.868 is significantly higher from that of the SMEs facing three challenges. This issue relates to the government policy in providing access to bank loans such as low-interest SME credits with simple approval procedure. The financial access provides the availability of financing to support the production of batik SMEs (Table 5) because, at the moment, there are many government loan facilities or low-interest loans available from banking partnership schemes or large companies. Nevertheless, most business owners are still confronted with the capital issue, collateral, and the absence of proper financial reports.

The capacity of technology and innovation (DINOV) was not found to affect substantially the competitive advantages of batik SMEs in Central Java, Indonesia. It means that, one of three ac- cesses (DINOV1), two of three accesses (DINOV2), and three accesses (DINOV3) proved to have the same impact on the competitive advantages of the batik industry as no access to technology at all. The technology access and product innovation improve the cost, such as the expense for innovation, the patent process, and certification. Thanks to the ability to also potentially improve the sales and prices through the improvement of quality, this will escalate the competitive advantages of batik SMEs for competition in markets. However, these entrepreneurs conduct the production process traditionally, and the business is inherited. The interest in technology and introducing innovation is low among batik SMEs because the aspects of technology and innovation are expensive and inefficient. While the employees of batik SMEs have sufficient competencies, they merely master the common products made on a daily basis. This confirms an explanation by Harvie (2004) that the issues of SMEs include the lack of capabilities related to the use of technology, processing high cost for a transaction to access infrastructure, and the difficulty in achieving quality standards.

In developing countries, the performance of batik SMEs is still plagued by many challenges due to a weak internal environment, the lack of information, and high risk and coordination costs. Besides the weak internal environment, they also face other challenges related to the access to input and output markets, access to information and loan facilities, and technical innovation assistance. The term "institutional challenge" emphasizes that the solutions to the challenges of batik entrepreneurs cannot be expected solely from them, but that a communal effort is required in the form of cooperation (Royer et al., 2016). From the aspect of input, the challenges relate to the lack of resources and poor access to finance and technology. Meanwhile, where the output aspect is concerned, the lack of market information, inspection and quality controls, and the connection to output markets are the main internal challenges. The lack of horizontal organization (between manufacturers) correlates to both input and output aspects.

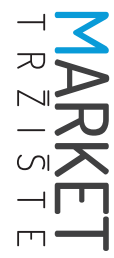




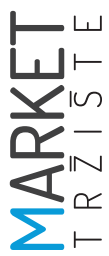

Royer and others (2016) explain that several institutional strategies used in reinforcing the value chain come from contracts that manufacturers conclude with partner organizations involved in the practice of strengthening SME institutions. Each arrangement will cut the institutional challenges by creating market connections (connecting buyers and manufacturers, assisting in negotiation, providing information on quality standards), preparing training and technical assistance, supporting institutional development, and certifications.

The business groups/cooperatives (DGROUP) was not found to affect significantly the competitive advantages of batik SMEs in Central Java, Indonesia. This result shows that the competitive challenges can be achieved by individual or group enterprises. If transaction cost is high, the collective effort in a business group will be more effective. If the expense in a collective effort is high, the effort will be less preferable. The batik industry on a large scale and export-oriented are as common as individual businesses.

The association of batik SMEs in the form of partnership (Akhtar, 1997) through vertical alliance and business groups in batik SME clusters can be explained through the agreement concept (cooperatives) because of the ability to save transaction costs and develop countervailing power in the following: 1) higher selling price - this is presumably the most important benefit from the advent of manufacturer association; 2) economy of scale - taking action on the same timeline will save certain expenses or improve the efficiency of a certain process; 3) external economics provide advantages, including the improvement of member productivity due to the information distribution; 4) non-economic advantages - the cooperative movement puts significant emphasis on non-economic advantages. The condition of perfect competition is the proxy of an equal number or sellers and buyers, and both act as price makers (Singh, 2008; Petrovic \& Milos, 2011; Huang \& CaO, 2015).
According to research results, the technology adoption (DTYPE) does not have a major impact on the competitive advantages of batik SMEs in Central Java, Indonesia. It means that competitive advantages of the batik SMEs producing a variation of the print, write, and combination types of batik are normally the same of those producing handmade batik. The export market access (DEXP) was not found to affect it considerably either, with no major difference in the competitive advantages evident between export-oriented batik SMEs and those that focus on domestic and local markets only. The region (DREGION) in which batik SMEs are located in Central Java, Indonesia also had no significant impact on their competitive advantages, meaning that the competitive advantages of batik SMEs from Rembang and Surakarta normally do not differ from those of batik SMEs from Pekalongan.

\section{CONCLUSION}

This research study proved that business scale, market access capacity, and financial access have a positive impact on the competitive advantages of batik SMEs in Central Java, Indonesia, while the capacity of technology and innovation, business groups/cooperatives, technology adoption, export market access, and region were not found to affect the competitive advantages of SMEs considerably.

The findings of this research imply that the capacity of markets and financial access drive the competitive advantages of batik SMEs in free trade markets. The smaller the scale of business, the lower its economy of scale efficiency to join the competition will be. Therefore, collective efforts can be made by batik SMEs through cooperatives to improve their economy of scale in accessing information and markets, as well as improving their access to financing and innovation. On the other hand, the role of cooperatives has not been entirely effective, as they have proven to be the least effective in reinforcing the influence of entrepreneur capacities to 
access information, markets and financing. To date, the cooperatives of batik SMEs have been mostly utilized to access financial aid and industry exhibition information facilitated by the government and foundations, but not to develop their business technology and innovation capacities. Those two capacities can be used more effectively as the source of competitive advantages for individual SMEs than for collective ones. The result of this research suggests that while cooperatives are required for access financial aids, industry exhibition information provision to batik SMEs facilitated by government or foundations etc., they should develop further to improve their economy of scale effi- ciency and access to information, innovation, and design to enable further competitive advantages to be gained in the era of technology and information globalization.

This research also has some limitations, namely: 1) the research is conducted in a developing country of Indonesia, so it needs to be applied in other countries with different economic and social background, culture, and regulation; 2) from the internal perspective, it only reviews the aspect of cooperatives as a form of non-market institutional management. Further research could explore the instrument aspect of macro institutions, such as government policy, in the system of institutional management.

\section{References}

1. Akhtar, M. R. (1997). Partnership financing of microenterprises. International Journal of Social Economics, 24(12), 1470-1480.

2. Akio, T. (2005). The Critical Assessment of the Resource-Based View of Strategic Management. Ritsumeikan international affairs, 3, 125-150.

3. Aldrich, H., \& Zimmer, C. (1986). Entrepreneurship through a social network. In: D. L. Sexton \& R. W. Smilor (Eds.), The Art and Science of Entrepreneurship (pp. 3-25). Cambridge: Ballinger Publishing.

4. Alston, L. J., \& Gillespie, W. (1989). Resource coordination and transaction costs: A framework for analyzing the firm/market boundary. Journal of Economic Behavior \& Organization, 11(2), 191-212.

5. Bandura, A. (1977). Social Learning Theory. Englewood Cliffs, NJ: Prentice-Hall.

6. Bank Indonesia (2016). Indonesia Banking Survey 2017 for SME lending. Bank Indonesia.

7. Bank Indonesia (2017). Message from the Governor of Indonesia Bank. Creative Work of IndonesiaCrafts Fair of SMEs Indonesia Bank, 1-6.

8. Barney, J. (1991). Firm resources and sustained competitive advantage. Journal of management, 17(1), 99-120.

9. Barrett, C. B. (2008). Smallholder market participation: concepts and evidence from eastern and southern Africa. Food Policy, 33, 299-317.

10. Committee of Donor Agencies for Small Enterprise Development - CDASED (1999). Business Development Services for SMEs: Preliminary Guidelines for Donor-Funded Interventions. Washington: Committee of Donor Agencies for Small Enterprise Development.

11. Charney, A., \& Libecap, G. D. (2000). Impact of Entrepreneurship Education: Kauffman Center for Entrepreneurial Leadership.

12. Chaston, I. (1992). Supporting new small business start-ups. Journal of European Industrial Training, 16(10), 3-8.

13. Chen, C. M., Delmas, M. A., \& Lieberman, M. B. (2015). Production frontier methodologies and efficiency as a performance measure in strategic management research. Strategic Management Journal, 36(1), 19-36.

14. Coase, R. H. (1937). The nature of the firm. Economica, 4(16), 386-405. 
15. Cromie, S. (2000). Assessing entrepreneurial inclinations: Some approaches and empirical evidence. European Journal of Work and Organizational Psychology, 9(1), 7-20.

16. Dorward, A., Poole, N., Morrison, J., Kydd, J., \& Urey, I., (2003). Markets, institutions, and technology: missing links in livelihoods analysis. Development Policy Review, 21, 319-332.

17. Duh, M. (2003). Family enterprises as an important factor of the economic development: the case of Slovenia. Journal of Enterprising Culture, 11(2), 111-130.

18. EIM Business \& Policy Research (1999). Dutch SMEs in European Perspective: Zoetermeer.

19. ESCAP (2009). Globalization of production and the competitiveness of small and medium-sized enterprises in Asia and the Pacific: Trends and prospects, Studies in Trade and Investment, No. 65. Bangkok, United Nations.

20. Galperin, E. A. (1985). Deterministic regression models for prediction and control. Mathematical Modelling, 6(2), 157-171.

21. Gibbons, P. T., \& O'Connor, T. (2003). Strategic posture, technology strategy, and performance among small firms. Journal of Enterprising Culture, 11(2), 131-146.

22. Gundry, L., Kickul, J., Welsch, H. P., \& Posig, M. (2003). Technological innovation in women-owned firms: Influence of entrepreneurial motivation and strategic intention. The International Journal of Entrepreneurship and Innovation, 4(1), 265-274.

23. Harvie, C. (2004). East Asian SME Capacity Building, Competitiveness, and Market Opportunities in a Global Economy, Working Paper 04-16. Department of Economics, University of Wollongong.

24. Hilton, R. W., Maher, M., \& Selto, F. H. (2003). Cost management: strategies for business decisions. Boston, MA: McGraw-Hill/Irwin.

25. Huang, M., \& Cao, L. (2015). The Relationship between Institutional Capital and Competitive Advantage: Literature Review and Future Research. Open Journal of Business and Management, 4(1), 94.

26. Huggins, R. (2000). The success and failure of policy-implanted inter-firm network initiatives: motivations, processes, and structure. Entrepreneurship and Regional Development, 12(2), 211-236.

27. Indonesian Central Bureau of Statistics (2016a). Population. Available at: https://www.bps.go.id/

28. Indonesian Central Bureau of Statistics (2016b). Statistic of Industry. Available at: https://www.bps. go.id/

29. Kirzner, I. M. (2015). Competition and entrepreneurship. Chicago, IL: University of Chicago Press.

30. Kolvereid, L. (1996). Prediction of Employment Status Choice Intentions. Entrepreneurship Theory and Practice, Fall, 47-57.

31. Kristiansen, S. (2002). Competition and Knowledge in Javanese Rural Business. Singapore Journal of Tropical Geography, 23(1), 52-70.

32. Kristiansen, S. (2003a). Information, Adaptation, and Survival: A study of small-scale garment and carpentry industries in Tanzania. Paper presented at the MU-AUC Conference, Dar es Salaam, Tanzania.

33. Kristiansen, S. (2003b). Linkages and Rural Non-Farm Employment Creation: Changing Challenges and Policies in Indonesia. Rome.

34. Kristiansen, S. (2004). Social network and business success: the role of sub-cultures in an African context. American Journal of Economics and Sociology, 63(5), 1149-1171.

35. Kristiansen, S., Furuholt, B., \& Wahid, F. (2003). Internet cafe entrepreneurs: pioneers in information dissemination in Indonesia. The International Journal of Entrepreneurship and Innovation, 4(4), 251-263.

36. Kristiansen, S., \& Indarti, N. (2004). Entrepreneurial Intention among Indonesian and Norwegian Students. Journal of Enterprising Culture, 12(1), 55-78.

37. Lieberman, M. B., \& Dhawan, R. (2005). Assessing the resource base of Japanese and US auto producers: A stochastic frontier production function approach. Management Science, 51(7), 1060-1075. 
38. Mahendra, E., Zuhdi, U., \& Muyanto (2015). Determinants of Firm Innovation in Indonesia: The Role of Institutions and Access to Finance. Economics and Finance in Indonesia, 61(3), 149-179.

39. Marsden, K. (1992). African Entrepreneurs - Pioneers of Development. Small Enterprise Development, 3(2), 15-25.

40. Mazzarol, T., \& Choo, S. (2003). A study of the factors influencing the operating location decisions of small firms. Property Management, 21(2), 190-208.

41. Mazzarol, T., Volery, T., Doss, N., \& Thein, V. (1999). Factors influencing small business startups. International Journal of Entrepreneurial Behaviour and Research, 5(2), 48-63.

42. McMahon, R. G. P. (2001). Growth and performance of manufacturing SMEs: The influence of financial management characteristics. International Small Business Journal, 19(3), 10-28.

43. Mead, D. C., \& Liedholm, C. (1998). The dynamics of micro and small enterprises in developing countries. World Development, 26(1), 61-74.

44. Meier, R., \& Pilgrim, M. (1994). Policy-Induced Constraints on Small Enterprise Development in Asian Developing Countries. Small Enterprise Development, 5(2), 66-78.

45. Milen, A., \& World Health Organization (2001). What do we know about capacity building?: an overview of existing knowledge and good practice.

46. Moore, I. (2014). Cultural and Creative Industries concept - a historical perspective. Procedia-Social and Behavioral Sciences, 25, 738-746.

47. Munir, G., Lim, M.K., \& Knight, L. (2014). Sustaining competitive advantage in SMEs. Procedia - Social and Behavioral Sciences, 25, 408-412.

48. Mulhern, A. (1996). Venezuelan small businesses and the economic crisis: reflections from Europe. International Journal of Entrepreneurial Behaviour \& Research, 2(2), 69-79.

49. North, D. C. (1991). Institutions. Journal of economic perspectives, 5(1), 97-112.

50. Nunally, J. C. (1978). Psychometric Theory. New York, NY: McGraw-Hill.

51. Olson, M. (1971). The logic of collective action: public goods and the theory of groups (No. 316.45). Boston, MA: Harvard University Press.

52. Pajares, F. (2002). Overview of Social Cognitive Theory and Self-efficacy. Available at: http://www. emory.edu/EDUCATION/mfp/eff.html

53. Petrovic, D., \& Milos, K. (2011). Transaction costs and the efficiency of institutions. Economics and Organization, 8(4), 379-387.

54. Porter, M. E. (2008). Competitive advantage: Creating and sustaining superior performance. New York, NY: Simon and Schuster.

55. Raposo, M. L., Ferreira, J. J., \& Fernandes, C. I. (2014). Local and cross-border SME cooperation: Effects on innovation and performance. Revista Europea de Dirección y Economía de la Empresa, 23(4), 157-165.

56. Reynolds, P. D., Hay, M., Bygrave, W. D., Camp, S. M., \& Autio, E. (2000). Global Entrepreneurship Monitor 2000 Executive Report: Babson College. London: Kauffman Center for Entrepreneurial Leadership, and London Business School.

57. Reynolds, P. L., Day, J., \& Lancaster, G. (2001). Moving towards a control technique to help small firms monitor and control key marketing parameters: a survival aid. Management Decision, 39(2), 113-120.

58. Royer, A., Bijman, J., \& Bitzer, V. (2016). Linking smallholder farmers to high-quality food chains: appraising institutional arrangements. Quality and innovation in food chains. Wageningen Academic Publishers, 1-274.

59. Ryan, T. R. (1970). Intentional Behavior: An Approach to Human Motivation. New York, NY: The Ronald Press Company.

60. Schumpeter, J. A. (1934). The Theory of Economic Development. Cambridge, MA: Harvard University Press. 
61. Shi, Z., Takala, J., Muhos, M., Poikkimaki, J., \& Chen, Y. (2013). SMEs' performance evaluation and optimization based on DEA and CFI. Management and Production Engineering Review, 4(1), 57-64.

62. Singh, N. (2008). Transaction costs, information technology, and development. Indian Growth and Development Review, 1(2), 212-236.

63. Singh, K. A., \& Krishna, K. V. S. M. (1994). Agricultural Entrepreneurship: The Concept and Evidence. Journal of Entrepreneurship, 3(1), 97-111.

64. Sinha, T. N. (1996). Human Factors in Entrepreneurship Effectiveness. The Journal of Entrepreneurship, 5(1), 23-39.

65. Smallbone, D., Leig, R., \& North, D. (1995). The characteristics and strategies of high growth SMEs. International Journal of Entrepreneurial Behaviour and Research, 1(3), 44-62.

66. Smith, A. (1776). An Inquiry into the Nature and Causes of the Wealth of Nations. In: S. M. Soares (ed.), The Theory of Moral Semtiments, Glasgow: MetaLibri Digital Library.

67. Steel, W. F. (1994). Changing the Institutional and Policy Environment for Small Enterprise Development in Africa. Small Enterprise Development, 5(2), 4-9.

68. Storey, D. (1994). Understanding the Small Business Sector. London: Routledge.

69. Suharno, Susilowati, I., Anggoro, S., \& Gunanto, E. Y. A. (2017). Typical Analysis for Fisheries Management: The Case for Small-Scaler of Shrimp Fishers. Advanced Science Letters, 23(8), 7096-7099.

70. Suharno, Susilowati, I., \& Firmansyah (2017). Management of the traditional milkfish culture in Indonesia: An approach using technical efficiency of the stochastic frontier production. AACL Bioflux, 10(3), 578-586.

71. Swierczek, F. W., \& Ha, T. T. (2003). Entrepreneurial orientation, uncertainty avoidance and firm performance: an analysis of Thai and Vietnamese SMEs. International Journal of Entrepreneurship and Innovation, 4(1), 46-58.

72. United Nations Conference on Trade and Development - UNCTAD (2008). Creative economy report 2008. Geneva: United Nations.

73. United Nations Educational, Scientific and Cultural Organization - UNESCO (2015). Cultural times The first global map of cultural and creative industries. Available at: http://unesdoc.unesco.org/images/0023/002357/235710E.pdf

74. Verhees, F. J. H. M., \& Meulenberg, M. T. G. (2004). Market Orientation, Innovativeness, Product Innovation, and Performance in Small Firms. Journal of Small Business Management, 42(2), 134-154.

75. Williamson, O. E. (2000). The new institutional economics: taking stock, looking ahead. Journal of economic literature, 38(3), 595-613.

76. Yuan, N., \& Vinig, T. (2007). Ownership Structure of Chinese SME's and the Challenges it Presents to Their Growth. Sprouts: Working Papers on Information Systems Number, 7(2), 2-19.

77. Zhu, Y., Wittmann, X., \& Peng, M. W. (2012). Institution-based barriers to innovation in SMEs in China. Asia Pacific Journal of Management, 29(4), 1131-1142. 